\title{
THE PORTRAIT OP A MODERN WOMAN IN THE POETRY OP WANDA MELCER
}

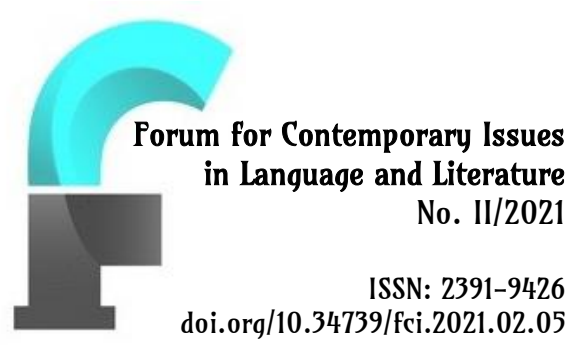

\author{
Sławomir Sobieraj \\ ORCID: 0000-0001-6332-692X \\ Siedlce University of Natural Sciences and Humanities \\ Faculty of Humanities
}

\begin{abstract}
The article tackles the topic of womanhood as a typical motif in Wanda Melcer's poetry, a topic which in historical-literary studies has so far been insufficiently discussed. Through the analysis of selected poems from her two published volumes as well as from other scattered poems, the portrait of a modern woman as presented in that poetry has been sketched out. This woman is a person who takes part in civilisational, social and manner-related changes. Her relations to culture, art and literature, her vitality and being active in life, all attest to her abandonment of roles imposed by the patriarchal system. It has been shown that the "new woman" breaks taboos and is educated. Above all she is independent and selfreliant, desires success and thirsts for new experiences, as demonstrated by how she frequently changes her surroundings and appropriates new spaces. She moulds her identity in confrontation with the outside world, she is open to otherness and changeability. At the same time she maintains personal consistency. Her creative identity is related to acting upon the principle of choice, and not obligation. Due to the multitude of biographical references present, the portrait of the female heroine contained in Wanda Melcer's poetry can be seen as a self-portrait of the author herself.
\end{abstract}

\section{Key words}

modernity, Wanda Melcer, female poetry, feminism, identity

\section{A new mentality}

Before a new wave of the feminist movement (led by Irena Krzywicka and Tadeusz Boy-Żeleński) developed in interwar Poland, and before the Customs Reform League and other organisations that demanded rights for women sprang up, Wanda Melcer created her own private front line in the fight for gender equality, something which was first reflected in her lyrical works. She wrote poems throughout the whole interwar period, but having published her second collection of poems she became more interested in prose. By boldly tackling taboos in both her novels and non-fiction works, she became a much appreciated writer and joined the artistic elites. In this area of her literary work, she expressed her support for feminism many times. 
However, one needs to keep in mind that it was poetry where she first showed herself to be a supporter of women taking on roles that were not hitherto foreseen for them in traditional Polish culture. Literary researchers have to date not paid much attention to this aspect. Only recently, on the margins of the discussion of "the feminisation of the avangarde", has there been an attempt to see Melcer's lyrical output in the context of issues related to breaking cultural barriers, as a female voice striving to release itself from silence (Kraj 2019, 63).

In her debut volume of poetry, published in 1917, the poet included many poems characterised by a break with the sentimentalism of Young Poland and a directness in presenting relations between men and women. One can assume that it was then, during her years of collaborating with Zofia Nałkowska, that Wanda Melcer's modern social and moral awareness was formed - under the influence of her colleague, who had more life experienced. An additional factor in this was, undoubtedly, the family traditions of emancipated, educated women, as well as social and education activists ${ }^{1}$.

In Passing Hours, alongside poems that echo Young Poland's atmospheric quality, one can also find several texts which are characterised by a reserved way of depicting feelings. The lyrical subject does not exhibit any tendency towards effusiveness, but it is more reflective. In Tęsknica (The Demon of Longing) and Samotność (Solitude), experiences that, in the preceding era, resulted in descriptions of a decadent breakdown become a pretext for a realisation in which one can see the mental strength of the speaker. The speaker thus delivers moral imperatives of Nietzschean origins, e.g. "I can feel creative power in myself", and "May your solitude be thunderbolt-like" (Melcer 1917, 7-8). Activeness of this sort demonstrates a process of going beyond oneself, the positive creation of a woman who has abandoned patterns of impotence: "Here I am - like a gushing, transparent spring,/ here I am, like a white, blossoming apple tree in an orchard” (Melcer 1917, 7).

In both of the quoted poems, Melcer praises life. Their vitalist tone is perhaps the result of the author's fascination with the works of Walt Whitman, whose works she translated into Polish, and who she introduced to readersin journalistic articles and lectures (Stradecki 1977, 283). She thus shared her adoration for the American poet with a young Julian Tuwim by preaching (just like the Skamander group did) a glorified view of the world (Melcer-Rutkowska 1920c, 8-9).

In her poem Perwersyjna księżniczka (The Perverse Princess), a seemingly banal and humorous story of a noble woman apt to have dalliances with men, one can identify an allegorical layer. It is a story of a woman who breaks moral conventions.

\footnotetext{
${ }^{1}$ The writer's mother, Helena, was a teacher; and her two sisters (Wanda's aunts) were engaged in public activities. Jadwiga Szczawińska-Dawidowa organised educational courses for women. Wanda Szczawińska, meanwhile, had two doctorates and contributed, among other things, to the foundation of a health pavilion for babies in the capital. The poem $W$ ochronce (At the Nursery), from the volume Płynące godziny (Passing Hours), is dedicated to her.
} 
She treats her unusual relationships with members of the opposite sex as if she were looking into their "souls' mirrors". Thus her nature is revealed, that of an explorer who wishes to go beyond the pre-determined role imposed on her (Melcer 1917, 61).

In Wanda Melcer's lyrical output, the question of self-reliance (both financial and social) is also present. The heroine of Westchnienie (A Sigh), who can be identified with the poet herself, is proud of her government job ${ }^{2}$, has an active social life and rubs shoulders with the capital's high society. She strolls along Nowy Swiat, one of the streets in the centre of Warsaw:

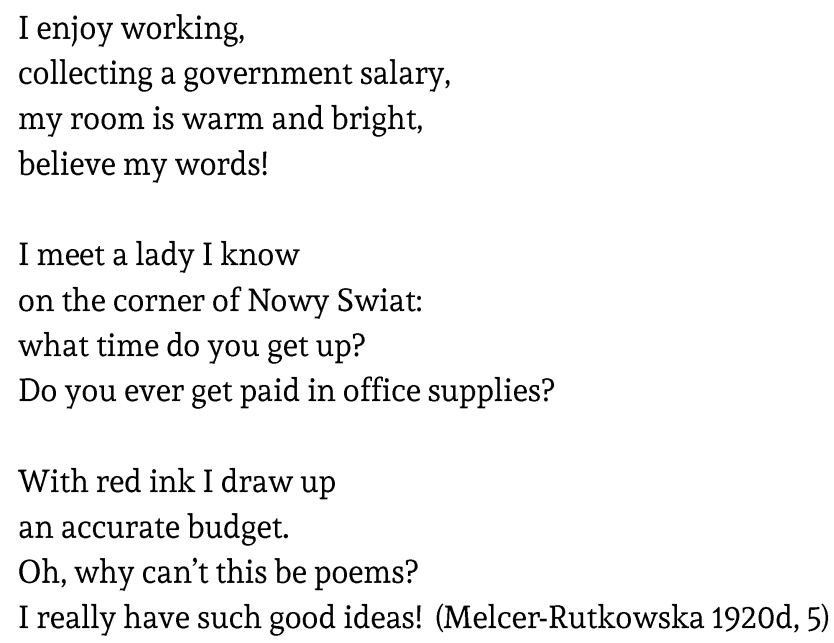

Introducing the name of the street, which evokes associations with expressions that were popular in intellectual circles after the end of the Great War (e.g. "the new man" or "a new beginning"), raises the idea of the world's renewal in the universal sense, which included the development of science and technology, as well as art and the social order. In the reborn Poland, it translated into a gradual equalling of women's rights (as far as education and participation in parliamentary elections was concerned), among other things. Hitherto, only a few women had had the opportunity to get a degree in higher education ${ }^{3}$

In the early 1920s, Melcer was one of the few members of the fairer sex who were employed in ministerial offices and were professionally successful. Since the postuprising times, office work had remained the domain of men, and women were left with mere housework, sewing and giving private lessons (Lisak 2009, 277). The poem's subject thus does appreciate her work, but misses writing poems.

\footnotetext{
${ }^{2}$ In the autumn of 1920, Wanda Melcer-Rutkowska found employment as a secretary in the Department of the Publishing Houses at the Bureau of Foreign Propaganda, part of the Council of Ministers (see Kotowska-Kachel 2013, 96). The poem draws on her real life, as it was published in December of that same year.

${ }^{3}$ Exceptionally, they were able to study Higher Education Courses for Women in Saint Petersburg, andat the philosophical and medical faculties at universities in Galicia (see Siemieńska 2019, 54).
} 
Despite increasing opportunities for women to attain a high social status, there were still limitations due to the stereotypical treatment of social roles ascribed to members of both genders by the patriarchal system (Gromkowska-Melosik 2011, 11-12). Melcer refused to be part of the traditional patterns, a state of affairs which was reflected in many of her works. This was related to going beyond the female " $\mathrm{I}$ ", the desire to be equal to men, the creation of a go-getting personality, and assuming a calm, unsentimental attitude. Melcer breaks with confessional poetry to take up unceremonious poetry in the style of Futurism, which is hardly surprising considering her relations with the avant-garde movement (her collaboration with the "Zwrotnica" circle and the avant-garde magazine "Blok"). In her poem "Atalanta", the heroine resembles a strong man. She wants to compete with him for primacy. She believes in her strength, and she boasts about her athletic body. Not its delicacy and beauty, but its sheer physical strength. This is a portrait of a modern emancipated woman, albeit a slightly masculinised one:

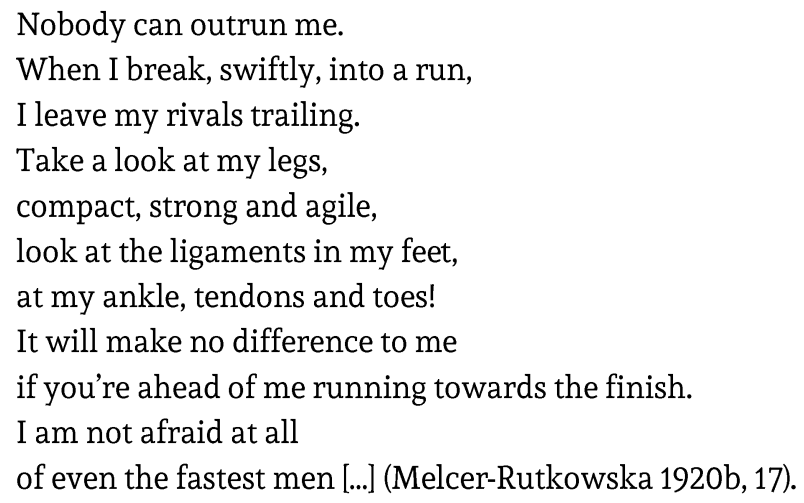

This is a one-of-a-kind identity transformation for a woman, one who is aware of not only being equal to men but also of being able to tower above them.

In Zarozumiałość (Conceit) the poem's female subject also reveals extraordinary ambitions. She refuses to consent to being oppressed. She objects to the old order and manifests a youthful energy which she believes will make her successful:

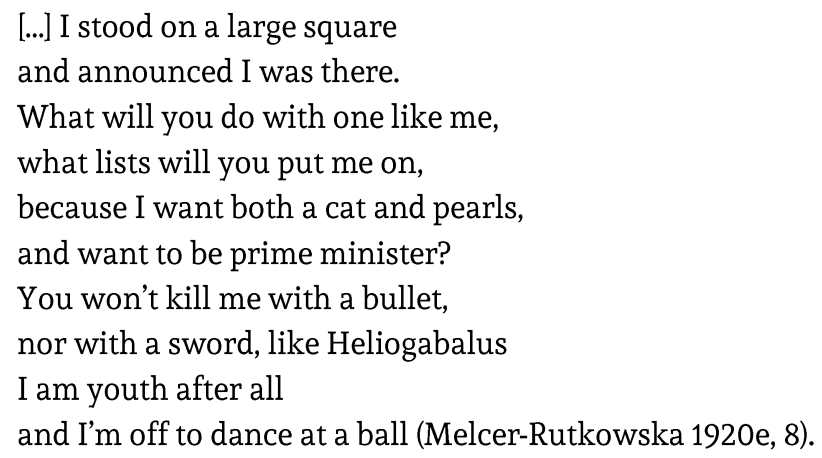


The role of leader, for centuries ascribed to men in Western European culture, becomes a challenge set by the heroine to herself and the whole world. Her desire for power might have been deemed controversial in the 1920s, nevertheless, she enters the fray by writing about herself as being as hard "as the edge of a sword of the best quality steel”. By assuming the male role, she does not give up her feminine identity; she prides herself on her beauty and wants to be regarded as attractive.

In many of Melcer's pieces, there are women in new social roles. These are, for example: an artist who's giving a public performance of a piano concerto (Popis, (Showing Off), a model revealing her body (Modelka, (The Model)), a reader of Hegel (Książki,(Books)), a traveller in a train compartment (Sleeping), a nude holiday-maker by the riverside (Na plaży, (At the Beach)), and writers (Głos (Voice), Poezja (Poetry), Lampka (A Lamp)). In her poem Gotowalnia (Boudoir), from her debut collection, the poet is already describing a mentally strong female who has confounded expectations so far:

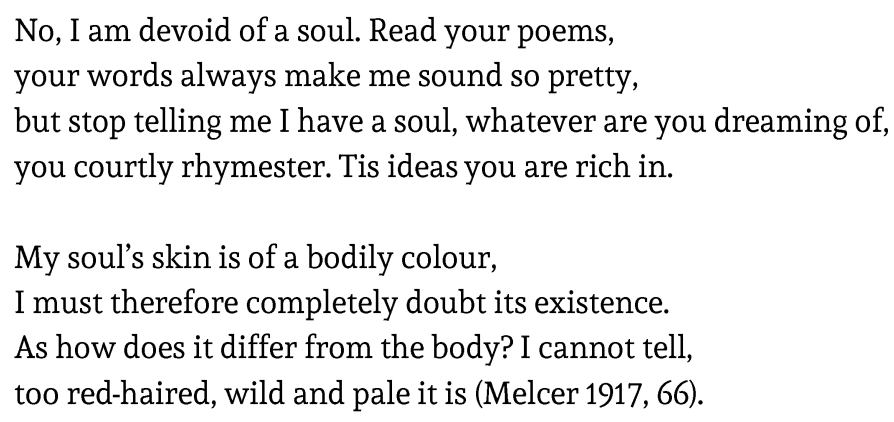

The declarations of the poem's subject, who opposes sentimental emotionality, accord with the critical discourse related to bourgeois customs. A woman's boudoir (the titular "gotowalnia") here becomes a place of physical and psychological transformation. The final metaphor presents the heroine as an actress who is performing a script made up by herself.

Melcer was not at all reluctant to present a woman's feelings in a non-prudish way, since in Egzaltacja (Exhaltation) she included a confession of passionate love:

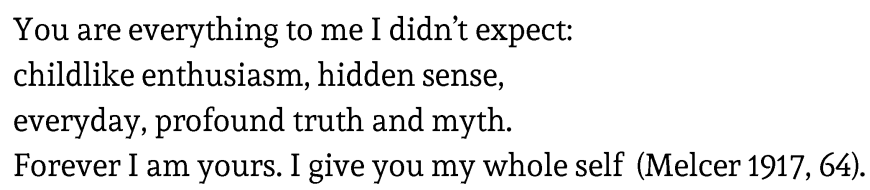

However, one must not forget that the female character Melcer creates is not only interested in the realm of feelings. Apart from a heart, she also has instincts, a body and a mind. She lets us know that she is a member of the intelligentsia on many occasions: she is familiar with Rembrandt and the drawings of the Japanese painter Hokusai (List(The Letter)), the works of the impressionists (Dwa sonety pointilistyczne 
(Two Pointillist Sonnets)) and those of the cubists (Rozłożone skrzypce (Deconstructed Violin)), and the tenets of the philosophy of Hegel (Książki (Books)), Leibniz (Kaprys (Caprice)), Rousseau (Inwokacja (Invocation)), and Plato.

\title{
2. Body and looks
}

The author of Passing Hours, deeply interested in the latest cultural phenomena, would engage in both literary and social activities even at a young age. Moral matters and gender equality were also of no less importance to her. Her positive attitude to avant-garde artists, who were bent on revolutionising many aspects of life by frequently tackling taboos in their works, is not surprising.

This was noticeable in biologism, a trend visible in the early works of those indulging in the new art forms. In the poetry of the Polish futurists it was related to primitivism, manifested in their praise of carnality and a sensual life, which was reflected in the first collections of poems by Anatol Stern (Delaperrière2004, 121-122), who just like Bruno Jasieński astounded readers with his erotic vocabulary. The "biologism" of avant-gardists points to the somatic nature of humans. It seems plausible to assume that their interests were not unfamiliar to Melcer; they might have also inspired her praise of the body, found in her poetry, a direct expression of which is the poem $W$ ciele ludzkiem (In the Human Body), which also includes a reflection upon physical-spiritual dualism:

\author{
In the human body I most adore the way \\ the arms are attached to the torso, the graceful line of the collarbone, \\ which along with the blade bones closes the ring that is the shoulders; \\ the deltoid muscles, underlined by angular shadows. \\ [...] I love the body's passing moods, \\ the disappointment of quiet, human misunderstandings. \\ I love inevitability, a powerful stream, \\ which flows through the stars and through my heart. (Melcer 1917, 25)
}

Melcer usually depicts the body as one of the inalienable attributes of womanhood. It can be strong if need be, but first of all it is imbued with allure. On many occasions, the things described in the female portraits are eyes, hands and lips. Occasionally, the motif of nudity appears, which highlights the expressiveness of the portrayal, an example of which can be found in The Model:

In a red rag, which almost reveals your divine breasts, round and ripe, like a sinful fruit during the grape harvest, in a red rag you have dressed your glory. 
And above your triumphant nudity,

which defends itself with just its shamelessness,

a red rag, dreams, which confuse the mind,

have you fastened together with the priceless clasp that is your hands (Melcer 1917, 26).

The bold act of presenting a woman's breasts as a reason for pride, though finished off by the focus on her hands - the clasping together of which may in body language suggest insecurity (as well as an attempt to control oneself) - is surprising. The gesture of clutching one's hands also appears in Niepokój (Unease), a poem that simultaneously shows a certain feeling as well as an awareness of the physical and biological existence of the poem's subject:

I am astonished at my naked neck

which I clasp my hands around.

I'm sitting and listening to what you say to me,

but I can hardly hear.

I am astonished at my naked neck

which I clasp my hands around (Melcer-Rutkowska 1920b, 18).

Becoming sensitive to the biological aspect of life appears, furthermore, in several texts that illustrate the strong connection between humans and flora and fauna. In contact with it, the lyrical subject finds calmness and consolation (in Jesion (Ash), Leszczyna (Hazel), Strumien (Stream)). Communing with nature brings joy as well; and spontaneous physical activity is also important, as in the poem Zabawa (Fun):

It's childlike happiness to run through virgin snow, to fall into the deepest snowdrifts, to jump over ditches, to laugh when underfoot fresh ice cracks, it will break and scatter, hit at full pelt.

And then, with a young pointer which barks happily, jumping, and putting its dirty paws on my fur coat, to look for a hare's footprints, which, a most skinny creature, hops around in the white snow near a forest in the distance (Melcer-Rutkowska 1920b, 46).

\section{Expansion of the boudoir}

A no less important question in depicting the modern woman is, for Melcer, the description of her boudoir, whose limits spread in the interwar period beyond the shelter of the home, located previously between the bedroom and the living room. An elegant lady feels at home in various places, including in new surroundings. Mirrors, which symbolise caring for and about one's appearance, appear with her in a lift, at a hairdresser's, and in a sleeping compartment on a train. Shop displays, with ladies' hats, become a ubiquitous element of the street landscape in a large town or city (in 
Wiosenny kapelusz (Spring Hat). These are areas marked by a civilization-related revolution, areas which exist due to various inventions and conveniences, and are the result of technologisation. In this respect, Melcer's annexation of the urbanised and machinised spheres connects her poetry with that of the futurists. In her poem $U$ fryzjera (At the Hairdresser's), changes in manners when it comes to the relationships that exist between the two genders have been masterfully captured:

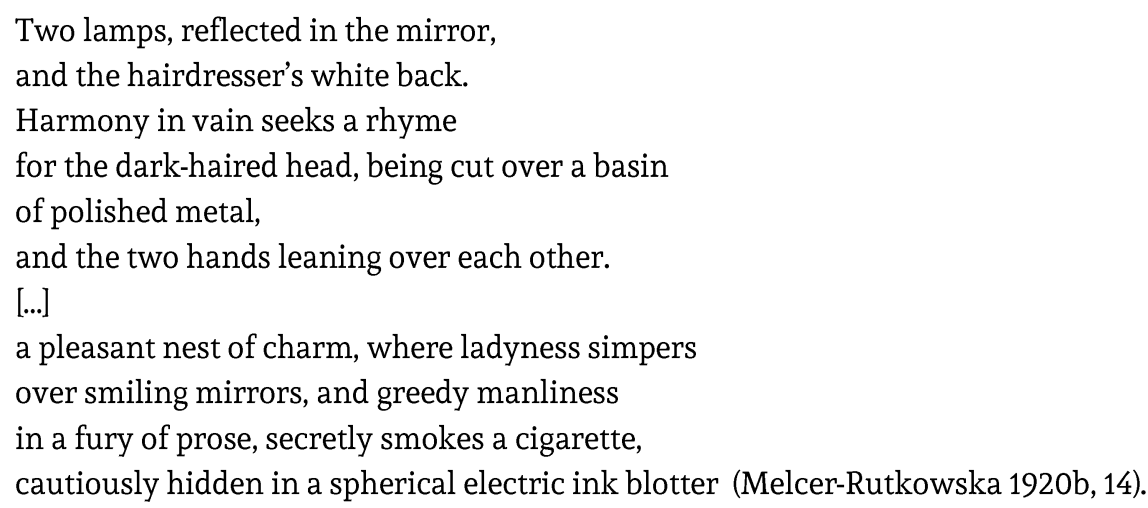

It is worth noting that the men in this genre scene are merely a background for the women. This is a new situation which may suggest a momentary change of roles. A man (the hairdresser) is either serving a woman, or (a husband or a lover) is waiting for her.

Accessories from a woman's boudoir can also be found far from an urban space, for example at a riverside beach, which is described in the first of the "pointillist sonnets":

Naked bodies on the sand tired by the sunny heat, children, young women. And a wave and its mane laps naked feet, resting on the sand.

A red parasol. A white head-scarf's tip (Melcer-Rutkowska 1920b, 48).

The modern woman, as the heroine of this non-traditional poetry, is a dynamic person and is constantly in motion; we meet her on streets, on a journey, at a dance. Of course, she never fails to be well-dressed. Various types of dresses dominate, such as those with ruffles and frills, and different ornaments, and apart from them there are hats and furs, or fur collars. From time to time one hears of a sapphire necklace (in Radość (Joy), and parasols and shoes (Marzenie (A Dream). A woman's attachment to detail becomes visible in the charming miniature Pióra (Feathers). Melcer shows off her artistry via concise and synthetic speech, which reveals one of the characteristic traits typical of the female gender, i.e. the desire to be seen as physically attractive:

Stylishly coiffured fans,

ostrich feathers, rolled up into curls, 
cool ones, spouting egret fountains,

and warm, animal-like, swan down:

all that is there

to help women be more beautiful (Melcer-Rutkowska 1920b, 23).

Wanda Melcer depicts a woman who sometimes devotes herself to jobs that are ascribed to her sex, such as embroidery; generally, however, she acts as energetically and as determined as a man. On some occasions she reveals her "dual identity" - she is independent and mentally strong, yet weak and lost at the same time - when she writes:

This is me,

proud,

not asking anyone for anything,

alone closed within myself,

commanding others.

This is me, the very same,

bitterly crying in an unfamiliar city,

helpless, like a child,

affectionate, poor, lost (Melcer-Rutkowska 1920b, 30).

In an equally interesting way, Melcer portrays herself in one of the poems she wrote at the end of the interwar period. A fur coat, associated with her in the memoirs of her contemporaries (Nałkowska 1980, 270), serves here as a metaphor not only for a Sunday (a day off work), but also for people and everyday matters, independence and mental strength:

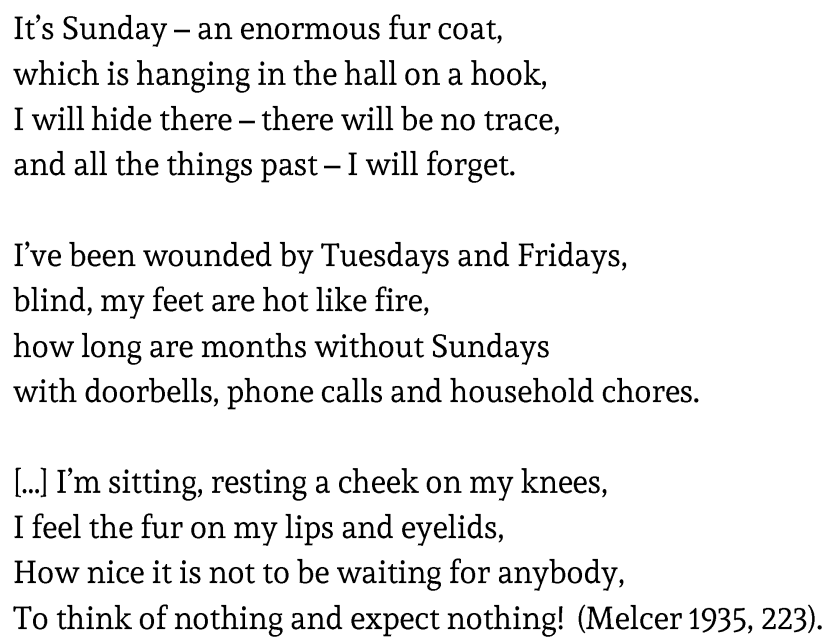

Here the background is days filled with hectic contact with other people and energetic activities, the latter having been subordinated to a preordained schedule accepted in advance, the calendar of ordinary busy days. 


\section{A "creative" identity}

Overcoming weaknesses that arise from the principles of living in a society, and also momentary personal setbacks, is an important character trait of the heroine in Wanda Melcer's poems, a heroine who in many aspects resembles the author herself. One could talk about poetic autobiographism, which usually is camouflaged due to the fact that proper names and dates are omitted. On the other hand, it can also be revealed ostentatiously, particularly in those poems, written in an avant-garde style, which break with the mental stereotypes of readers and the critics. A hint at the biographical interpretation of those works is also offered by one of Melcer's polemics in which she identifies herself with the lyrical subject of the poem $\operatorname{Koty}($ Cats) (Melcer-Rutkowska 1920a, 11-12).

The bold role of a female writer, which can be seen in several texts but primarily in the title of Melcer's second volume of poems, was - at the turn of the second and third decade of the 20th century - an act of challenging and "ignoring the humility that had been imposed for ages" (Kłosińska 2009, 95). It is worth remembering that, at the same time, several female poets were still hiding behind male pseudonyms because they lacked the courage to reveal their identity.

Many years ago, Jerzy Kwiatkowski aptly noted that in the early interwar period certain strivings of female writers became apparent: they were fighting for equal rights between the sexes and mutual "freedom and sincerity in erotic culture". However, it is impossible to agree with his categorical claim that Maria PawlikowskaJasnorzewska was most important when it came to emancipatory activities in poetry (Kwiatkowski 1972, XII-XIII). Several years Pawlikowska-Jasnorzewska's junior, Wanda Melcer, who published the majority of her poems before the debut of the author of Blue Almonds even came out, undoubtedly preceded her in pursuit of independence.

Wanda Melcer's portrait of a modern woman was sketched in her poetry in a multiaspectual way. Her modern woman is a person who takes part in civilisational, social and manner-related changes. Her life's activities bear witness to the abandonment of roles imposed by the patriarchal system. The new woman breaks taboos (she does not avoid the topics of nudity, the right to be a member of the government, or to take part in education or artistic activities), and she is educated. Above all, she is independent and self-reliant. She does not need a guardian, she is looking more for a partner. She is also ambitious and creative, thirsty for success and hungry for new experiences, as demonstrated by how she frequently changes her place of abode and appropriates new spaces. She confronts the outer reality, she is open to otherness and changeability, but at the same time she longs to create her own world. That act of creation takes places via a search for the rules governing how one co-exists with one's environment. Just like Pawlikowska-Jasnorzewska, she experiences herself through engaging with nature, other people, or the world of 
culture, but she believes in the rule of choice and not obligation. Only this can guarantee that the harmony of an individual being is discovered, a harmony which is related to feeling closeness, acceptance, satisfaction and fascination (Morzyńska-Wrzosek 2013, 34-35).

In the poetry in question, the planned act of erasing gender differences in some relationships between humans is accompanied by a desire to highlight female distinctiveness. This applies to the aesthetic sphere in particular, but it also concerns the manner-related and psychological realms to some extent. The content of these ideas is reflected in Melcer's varied style and changeable forms of lyrical expression, which are often connected to the avant-garde concepts of the futurists and expressionists (cf. Sobieraj 2018, 173-174; Sobieraj 2020, 171-172; Kraj 2019, 72-75).

\section{Portrait - Self-portrait}

In Wanda Melcer's poems that depict a modern woman one can see a reflection of herself: an extraordinary and controversial personality with liberal views, demonstrating nonconformist behaviour, and interested in avant-garde art. Her utterances sometimes take the form of a story about her own life and one can find evidence of the "identiticality and narration's narrator", which makes it possible to state that there is an autobiographical element (Starobinski 1979, 307).

First of all, one should point to the feminist perspective of the poetry, which is most evident in the title of the collection Na pewno książka kobiety (A Woman's Book for Sure). In almost every one of the poems included there, there is a first-person "I" speaking, and it specifies her gender either by using feminine verb forms or one can deduce this information from the situations. The lyrical subject's revealing of her female gender makes it possible (in accordance with Grażyna Borkowska's assumptions) to talk about women's poetry in this case too (Borkowska 2009, 71). After all, Melcer herself got involved in the activities of the League for the Reformation of Manners, even though that was slightly later, when she had given up writing poetry in favour of prose. When it came to journalism, she was also concerned with the then thorny problems of the fight for equality.

The various incarnations and professions of the heroines in Melcer's poems are, on many occasions, a reflection of her own jobs and public activities. Apart from her autotelic poems, in which the lyrical subject presents herself as a female poet (e.g. Głos (Voice)), it is worth noting others, such as the poem Pociecha (Consolation), which probably concerns the public talks and readings given by the author at the Polish Artistic Club, or Westchnienie (A Sigh), which describes her thoughts after taking up a position at the ministerial Department of Publishing Houses. On the other hand, Atalanta is a reflection of Melcer's interest in sports; moreover, it is known that she was a member of the "Grażyna" sports club, based in Skaryszewski Park in Warsaw (Kotowska-Kachel 2013, 97). 
A separate group is made up of poems about painting(s), which demonstrate the author's knowledge of the latest contemporary movements in art, knowledge she probably acquired while studying at the School of Fine Arts in Warsaw (Kotowska-Kachel 2013, 96). Yet she was also interested in sculpture and embroidery, which she displayed at an exhibition shared with her husband; she also commemorated these interests in two texts (Hafty (Emroidery), Sen (Sleep)).

On the other hand, musical elements (e.g. in Symfonii Straussa (Strauss' Symphony)) can be associated with the writer's father. Many of the poems from the first volume refer to her father and other close family and friends, especially in the frequent dedications. The cycle Dziewięć sonetów wiejskich (Nine Countryside Sonnets) is dedicated to her father, while the poem Odchodzę (I'm Leaving) is dedicated to her mother, $W$ ochronce (At the Nursery) goes to her aunt Wanda Szczawińska, and Inwokacja (Invocation) is to Zofia Rygier-Nałkowska. Some of the statements contain slivers of the poet's memories of various places she had visited: Łazienkowski Park in Warsaw (Pałac Eazienkowski (Eazienkowski Palace)), the museum in Nuremberg (Puchar narzeczonej (Fiancée's Cup)), Switzerland (e.g. Górska wycieczka (Mountain Excursion)), the countryside, or unfamiliar cities. There are quite a lot of poems that show the lyrical subject on a journey. They are short and long journeys, local and foreign, by carriage or by train (W obcym mieście (In an Unfamiliar City), Rozjazdy (Departures), and Sleeping (Sleeping)). In A Dream, where exceptionally a proper name appears - that of the town Włocławek (which is an unambiguous hint at the hometown of Melcer's first husband, painter Szczęsny Rutkowski), the writer's idée fixe is included. Several years later it would find an outlet not only in her reportage writings, but also in her various travels across Europe and even to the Southern hemisphere (to Argentina and Brazil). This can be seen in the following excerpt:

The ground burns me, wherever I step, through the thin soles of my little shoes.

I have just returned, and again

I would like to go somewhere.

I don't care where,

and I don't know at all why.

I try to guess but can't for the life of me.

It might as well be to that Włocławek,

whence I came not long ago.

It might as well be to that same village

where I rode a horse in winter.

The ground burns me, as it has done

to so many poets by accident (Melcer-Rutkowska 1920b, 26). 
The lyrical subject's self-identification as the poet and traveller, Melcer, gives reason enough to treat this attitude as an aspect of nomadic existence. And once again the issue of building one's own identity by recognising what's different and unknown rears its head. Both Melcer and the heroine she creates in her poems are energetic and dynamic people. Their life is determined by movement, action and a proactive attitude to their surroundings. The portrait of a modern woman, engaged in the revolutionary socio-cultural changes of the interwar years, as sketched in the poetry of the author of Święta kucharka (The Holy Cook), simultaneously becomes her selfportrait.

\section{Bibliography}

Borkowska, Grażyna. 2009. Metafora drożdży. Co to jest literatura/poezja kobieca, in: Ciało $i$ tekst. Feminizm w literaturoznawstwie - antologia szkiców, ed. by A. Nasiłowska, Warszawa, 65-76.

Delaperrière, Maria. 2004. Polskie awangardy a poezja europejska. Studium wyobraźni poetyckiej, transl. by A. Dziadek, Katowice.

Gromkowska-Melosik, Agnieszka. 2011. Edukacja i (nie)równość społeczna kobiet. Studium dynamiki dostępu, Kraków.

Kłosińska, Krystyna. 2009. Kobieta autorka, in: Nasiłowska A. (ed.), Ciało i tekst. Feminizm w literaturoznawstwie - antologia tekstów, 94-116. Warszawa.

Kotowska-Kachel, Maria. 2013. Sztekkerowa Wanda, in: A. Romanowski (ed.), Polski Słownik Biograficzny, Vol. XLIX/1, Issue 200, Warszawa - Kraków.

Kraj, Łukasz. 2019. “Feminizowanie awangardy? Na pewno książka kobiety Wandy Melcer”. Pamiętnik Literacki CX, Issue 3: 59-75.

Kwiatkowski, Jerzy. 1972. “Wstęp”. In Pawlikowska-Jasnorzewska M., “Wybór poezjī, $3^{\text {rd }}$ edition (extended), Wrocław.

Lisak, Agnieszka. 2009. Miłość, kobieta i małżeństwo w XIX wieku, Warszawa.

Melcer, Wanda. 1935. Niedziela, "Skamander", no. 59.

Melcer, Wanda. 1917. Płynące godziny, Warszawa.

Melcer-Rutkowska, Wanda. 1920a. Apologia “Kotów”, “Gospoda Poetów”, no. 2.

Melcer-Rutkowska, Wanda. 1920b. Na pewno książka kobiety, Warszawa.

Melcer-Rutkowska, Wanda. 1920c. Walt Whitman - prorok Ameryki, “Kurier Polski”, no. 139.

Melcer-Rutkowska, Wanda. 1920d. Westchnienie “Kurier Polski”, no. 346.

Melcer-Rutkowska, Wanda. 1920e. Zarozumiałość. “Gospoda Poetów”, no. 3.

Morzyńska-Wrzosek, Beata. 2013. “i na piękność, i na wyczyn burzy”. Proces kształtowania tożsamości w poezji Marii Pawlikowskiej-Jasnorzewskiej, Bydgoszcz.

Nałkowska, Zofia. 1980. Dzienniki, t. III, 1918-1929, edited by H. Kirchner, Warszawa. 
Siemieńska, Renata. 2019. Kariery akademickie w Polsce w XIX i XX wieku: czy płeć je różnicowała? In Kariery akademickie kobiet i mężczyzn. Różne czy podobne?, edited by R. Siemieńska, Warszawa, 51-71.

Sobieraj, Sławomir. 2018. Awangarda mniej znana, Siedlce.

Sobieraj, Sławomir. 2019. "Zapomniana poezja Wandy Melcer-Rutkowskiej”. Conversatoria Litteraria, no. 13: 233-246.

Sobieraj, Sławomir. 2020. “Transgresje i wiwifikacje. Wandy Melcer liryka nowoczesna”. Зборник Матице Српске За Славистику - Journal of Slavic Studies, no. 97: 171-85.

Starobinski, Jean. 1979. “Styl autobiografii”, transl. by W. Kwiatkowski. Pamiętnik Literacki, issue 1: 307-316.

Stradecki, Janusz. 1977. W kręgu Skamandra, Warsaw. 